Semmelweis Egyetem Á0K, II. Belgyógyászati Klinika, Budapest, ${ }^{1}$ Semmelweis Egyetem, Laboratóriumi Medicina Intézet, Budapest, ${ }^{2}$ MTA-SE „Lendület” Örökletes Endokrin Daganatok Kutatócsoport, ${ }^{3}$ MTA-SE Molekuláris Medicina Kutatócsoport ${ }^{4}$

\title{
A kromogranin-A szerepe diabetes mellitusban humán vizsgálatok és állatkísérletek alapján
}

\author{
Herold Zoltán, ${ }^{(1)}$ Patócs Attila dr., ${ }^{(2,3)}$ Doleschall Márton dr., ${ }^{(4)}$ Somogyi Anikó dr. ${ }^{(1)}$
}

\begin{abstract}
Összefoglalás
A kromogranin-A a granin fehérjecsaládba tartozik, különbözö szervek endokrin és neuroendokrin sejtjei termelik. Számos ismert vagy mind ez ideig kevésbé tisztázott funkciójú, kisebb fehérje hasad ki belöle. A klinikumban elsösorban a neuroendokrin sejtes daganatok kimutatására, illetve azok terápiás követésére alkalmazzák.

A kromogranin-A és a cukorbetegség kapcsolatának vizsgálata friss kutatási terület. A fehérje diabetesben betöltött pontos szerepe egyelöre nem tisztázott, de erös kapcsolatra utal, hogy az 1-es típusú cukorbetegség modellállataiban, a nem-obes diabeteses egerekben, ha a kromogranin-A gént kiütötték, hím egereknél nem, míg nöstényekben is csak nagyon ritkán alakult ki a betegség, összehasonlitva a vad típusú, nem-obes diabeteses egerekkel.

A pankreasztatin szabályozza a cukor-, zsir- és fehérje-anyagcserét a májban és a zsírszövetben. A WE-14 és további kromogranin-A-fragmentumok mind a humán klinikai vizsgálatok, mind egerekkel végzett állatkísérletek alapján a $\beta$-sejtek elpusztitásában részt vevö CD4 és CD8 ${ }^{+}$T-sejtek autoantigénjeiként funkcionálnak. Kontrollszemélyekhez képest a szérumban magasabb kromogranin-A-, pankresztatin-és WE-14-koncentrációkat mutattak ki mind 1-es típusú, mind 2-es típusú és gestatiós diabetesben szenvedö betegekben.

A bemutatott adatok alapján a kromogranin-A a diabetes mellitus kialakulásában, patomechanizmusában fontos szerepet játszhat. Az eddigi ismeretek alapján a cukorbetegség és a fehérje további kapcsolatának vizsgálata szükséges.

Kulcsszavak: kromograninok, egerek, veleszületett NOD, diabetes mellitus, CD4-pozitiv T-lymphocyta, CD8pozitiv T-lymphocyta
\end{abstract}

\section{The role of Chromogranin-A in diabetes mellitus based on human clinical and animal model studies}

Summary: Chromogranin-A, produced by the endocrine and neuroendocrine cells of different organs, is a family member of the granin proteins. It has cleavage products with well-known biological function, while the role of other products has not been fully understood yet. Its elevation in serum is currently used as a marker in the diagnostics of neuroendocrine cell originated tumors.

The relationship between Chromogranin-A and diabetes mellitus is an ongoing research area. Its exact role in diabetes has not been clarified, but a notable connection has been inferred through type 1 diabetes mellitus is not developed in Chromogranin-A gene knockout male, non-obes diabetic mouse models, and it is sparsely observed in knockout female mice compared to wild type non-obese diabetic mice.

The cleavage products pancreastatin and WE-14 are related to various types of diabetes. Pancreastatin has a regulatory function in the sugar, fat and protein metabolism of liver and adipose tissue. WE-14 and other small Chromogranin-A fragments are autoantigens for the $\beta$-cell destructive diabetogenic CD4 and CD8 ${ }^{+} T$-cells in both human and non-obese diabetic mice. Higher Chromogranin-A, pancreastatin and WE-14 levels have been reported in type 1, type 2 and gestational diabetic patients than in healthy controls.

Chromogranin-A may play an important role in the development and pathogenesis of diabetes mellitus according to the presented studies, and further studies are needed to investigate this relationship. 
Keywords: chromogranins, mice, inbred NOD, diabetes mellitus, CD4-positive T-lymphocytes, CD8-positive T-lymphocytes

Rövidítések

BDC: A Barbara Davis Center for Childhood Diabetes munkatársai által felfedezett szigetsejt-specifikus T-sejt klón populációk; CD: csoportdetermináns fehérjék (cluster of differentiation); CgA: kromogranin-A (chromogranin-A); DNS: dezoxiribonukleinsav; ELISA: enzimhez kapcsolt immunszorbens vizsgálat (enzyme-linked immunosorbent assay); KO: génkiütött (gene knockout); MHC: fö hisztokompatibilitási komplex (major histocompatibility complex); mRNS: hírvivő ribonukleinsav (messenger ribonucleic acid); NO: nitrogén-monoxid (nitric oxide); NOD: nem-obes diabeteses (non-obes diabetic); PST: pankreasztatin (pancreastatin); RIA: radioimmunesszé (radioimmune assay); RLGL: arginin-leucin-glicin-leucin; SDS-PAGE: nátrium-dodecil-szulfát poliakrilamid gélelektroforézis (sodium dodecyl sulfate polyacrylamide gel electrophoresis); TGáz: transzglutamináz enzim

A kromogranin-A az endokrin rendszerhez köthető, testszerte termelődő fehérje, amelyből számos ismert vagy kevésbé tisztázott funkciójú, kisebb molekulatömegű fehérje hasad ki. Az elmúlt években megjelent tanulmányok alapján mind az alapmolekulának, mind a hasítási termékeknek kapcsolata van a cukoranyagcserével, illetve szerepük van a diabetes mellitus patomechanizmusában.

Az összefoglaló közlemény célja, hogy a rendelkezésre álló irodalmi adatok alapján tárgyalja a kromogranin-A és a cukorbetegség összefüggéseit a kromogranin-A általános jellemzőinek fényében.

\section{A kromogranin-A biológiai jellemzői}

A granin glukoprotein családba tartozó CgA 439 aminosavból (48 kDa) áll, savas kémhatású, hidrofil fehérje. A szervezetben testszerte fellelhető, különböző endokrin és neuroendokrin sejttípusok szintetizálják. Felfedezése Blashko és mtsai nevéhez füződik: 1967-ben szarvasmarhavesék kromaffin típusú granulumaiból izoláltak több szolúbilis fehérjét, amelyeket kromograninoknak, míg a fő komponenst kromogranin-A-nak nevezték el. ${ }^{1,2}$ A humán CgA-t kódoló gén a 14. kromoszómán található, 12 kilobázis hosszúságú és 8 exonból áll. ${ }^{3}$

A fehérje termelése humán szervezetben először a 6. és 8. embrionális héten észlelhető a mellékvesék primordiumaiban és az emésztőszervek endokrin sejtjeiben, majd a 9. embrionális héttől a kromaffin sejtek előalakjaiban. ${ }^{2}$ Felnőttekben a mellékvese velőállományának kromaffin sejtjeiben, illetve a gyomor-bél traktusban található diffúz neuroendokrin rendszer szimpatikus idegrostjainak elektrondenz vezikulumaiban termelődik a legnagyobb mennyiségben, de CgA-t termelő sejtek helyezkednek el a központi és perifériás idegrendszer, az agyalapi mirigy és a mellékpajzsmirigy kalcitonintermelő C-sejtjeiben is. Megfigyelték a pancreas inzulin- és glukagontermelő exokrin szöveteiben, illetve a tüdőben, a lépben, a prosztatában és a csecsemőmirigyben is. ${ }^{4,5}$ A CgA termelése cirkadián ritmust mutat: reggel alacsonyabb és este magasabb. ${ }^{6}$

Bioszintézisének szabályozásában részt vesz többek között a proteinkináz C, a hisztamin, a nikotin, az angiotenzin II, a prosztaglandin E2, a káliumionok és a glukokortikoidok, amelyek fokozzák, míg az ösztrogén gátolja a termelését. ${ }^{3}$

A fehérje poszttranszlációs módosulásaival számos, ismert biológiai aktivitású molekula jöhet létre, mint pl. a pankreasztatin, a $\beta$-granin, a kromosztatin, a vazosztatin és a parasztatin (1. ábra). ${ }^{7}$ Egyes feltevések szerint további, mind ez ideig még fel nem fedezett hasadási termékek is képződhetnek belőle.,

\section{A WE-14 felfedezése, biológiai jellemzői}

A CgA-ból lehasadó WE-14 fehérjét $\left(\mathrm{CgA}_{324-337}\right)$ Curry és mtsai izolálták először a középbél karcinoid sejtjeiből. ${ }^{9}$ Elnevezésére a fehérjemolekula hosszát (14), illetve az $\mathrm{N}$ - és C-terminális végen található aminosavak egybetűs jelölését (W: triptofán, 


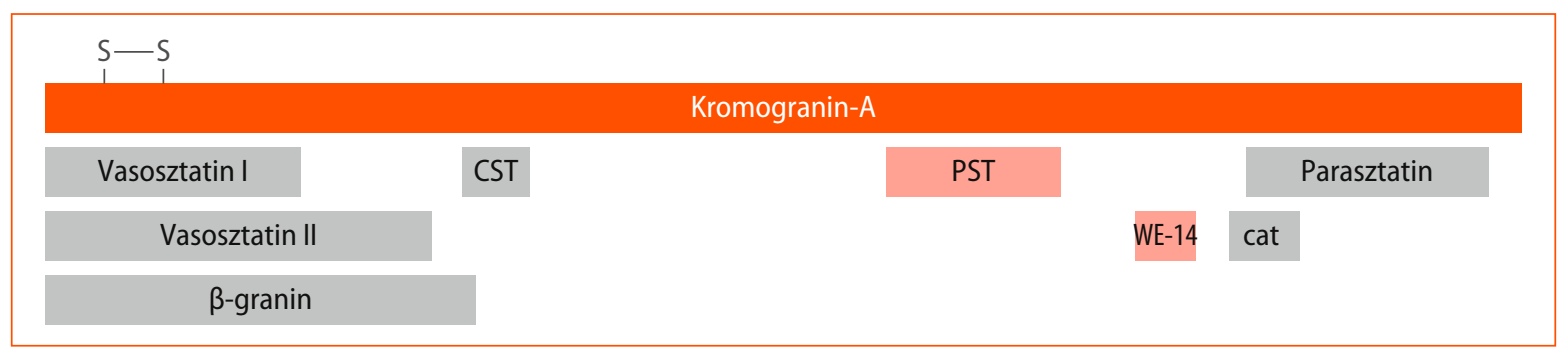

1. ábra. A kromogranin-A szerkezete és hasitási termékei: $\beta$-granin $\left(C g A_{1-128}\right)$, vazosztatin I és II $\left(C g A_{1-76 \prime} C g A_{1-115}\right)$, kromosztatin (CST) ( $\left(\mathrm{Cg}_{124-143}\right)$, pankreasztatin (PST) $\left(\mathrm{CgA}_{250-301}\right), W E-14\left(\mathrm{Cg}_{324-337}\right)$, katesztatin (cat) $\left(\mathrm{CgA}_{352-372}\right)$ és parasztatin $\left(\mathrm{Cg}_{357-428}\right)$. A diabetes mellitusszal kapcsoltságot mutató fehérjék narancs háttérrel vannak kiemelve (Herold Z et al., Orvosi Hetilap 2015. alapján) ${ }^{7}$

E: glutaminsav) használták. Később Guillemot és mtsai primer pheochromocytoma sejttenyészeteiből - a mellékvesevelő kromaffin sejtjeiből kialakuló, katekolamintermelő tumorból - is ki tudták mutatni, valamint igazolták, hogy a fehérje megtalálható a kromaffin sejtekben normál, tumormentes állapotban és már embrionálisan is. Igazolták, hogy mint a CgA, a WE-14 is könnyen vizsgálható egészséges egyének véréből vett mintákból..$^{10}$ A WE-14 izolálható volt még a hasnyálmirigy $\beta$-sejtjeiben és egyéb gastro-entero-pancreaticus szövetekben is. ${ }^{11}$

\section{A pankreasztatin felfedezése, biológiai jellemzői}

Az emlősök neuroaktív, illetve hormonálisan aktív fehérjéinek közel felére jellemző, hogy C-terminális végükön egy amid struktúrát tartalmaznak. Ennek az $\alpha$-amid struktúrának a felismerésére dolgozta ki az 1970-es évek végén Tatemoto és munkacsoportja azt a módszert, amely során a feldolgozott szövetmintából enzimes kezelés hatására csak azok a fehérjék szabadulnak fel, amelyek az $\alpha$-amid struktúrát tartalmazzák. Az így nyert fehérjéket fluoreszcens anyaggal történő kezelést követően vékonyréteg-kromatográfiás módszerrel vizsgálták tovább. A módszerrel számos neuro- és hormonális aktív fehérjét izoláltak, a felfedezett fehérjék azonosításán kívül a legtöbb esetben azok funkciójáról azonban információval nem tudtak szolgálni. ${ }^{12}$

1986-ban izoláltak sertéshasnyálmirigyből egy 49 aminosav hosszúságú, a glukóz stimulálta inzulinszekréciót gátló peptidet, amelyet PST-nek neveztek el. ${ }^{12} \mathrm{~A}$ fehérje aminosavsorrendjének ismeretében még a felfedezés évében megjelent több publikáció, hogy a PST jelentős hasonlóságot mutat a szarvasmarha-CgA egyes szakaszaival. A két fehérje közötti kapcsolatot végül 1988-ban igazolták: meghatározták a sertés-CgA fehérje teljes DNS-szekvenciáját, ami magában foglalta a teljes hosszúságú PST-szekvenciát is. Ezt követően a humán CgA szekvenciáját is megvizsgálták, a sertés-PST-vel kb. 70\%-os egyezést igazoltak. ${ }^{13}$

\section{A kromogranin-A diagnosztikai felhasználása}

A CgA kimutatása szérum- vagy plazmavérmintákból, ELISA, illetve RIA technikákkal lehetséges. A nemzetközi ajánlásoknak megfelelően csak a CisBio cég által fejlesztett, kettős, monoklonális antitestet használó immunohisztokémiai, ELISA és RIA reagensei mutatnak pontos koncentrációkat. ${ }^{8}$

A vér $\mathrm{CgA}$-koncentrációja informatív a neuroendokrin eredetű daganatok kimutatása során, mivel a legtöbb esetben a $\mathrm{CgA}$ vérkoncentrációja sokszorosan meghaladhatja a normál tartomány $(19,4-98,1 \mathrm{ng} / \mathrm{ml})$ felső határát. ${ }^{14}$ A legmagasabb szérum-CgA-koncentrációkat a vékonybél karcinoid tumorai és a hasnyálmirigy szigetsejtjeinek karcinómái esetében regisztrálták. ${ }^{8,15}$ A diagnózis felállítása mellett vizsgálata alkalmas a kezelés eredményességének, a tumoros folyamatok progressziójának, kiújulásának nyomon követésére is. ${ }^{16}$

A tumoros elváltozásokhoz hasonlóan, emelkedett koncentrációk figyelhetőek meg, ha a vizsgált személy atrophiás gastritisben, előrehaladott 
májelégtelenségben, valamilyen gyulladásos bélbetegségben (pl. Crohn-betegség) vagy szívelégtelenségben szenved. A legmagasabb, nem tumorokhoz köthető és az előzőeknél jelentősebb CgA-növekedést veseelégtelenségben figyelték meg. ${ }^{17,18}$

Fontos megjegyezni, hogy - a másodlagos hypergastrinaemiát és a gyomor enterokromaffinszerű sejtjeinek serkentését okozó - a savszekréció-gátlás (pl. protonpumpagátló vagy hisztamin $\mathrm{H}_{2}$-receptorblokkoló kezelés) és az atrophiás gastritis a kóros koncentrációnak megfeleltethető tartományba emelheti a CgA-szinteket. ${ }^{19,20}$ Ezért a CgA-meghatározást megelőzően a savcsökkentő kezelések felfüggesztése, legalább három felezési idő erejéig (kb. 1 hét) szükséges. ${ }^{19}$

\section{A kromogranin-A és hasítási termékeinek kapcsolata a szénhidrát-anyagcserével és a diabetes mellitusszal}

A cukorbetegség napjaink egyik legjelentősebb népegészségügyi problémája, a világ lakosságának kb. 8-9\%-a szenved a betegségben. ${ }^{21}$ Habár a betegség patomechanizmusának irodalma igen jelentős, számos, a diabetes kialakulása és progressziója során szerepet játszó molekula és a betegség kapcsolatának feltárása friss kutatási terület. ${ }^{22}$ Ilyen például a $\mathrm{CgA}$ és annak pankreasztatin $\left(\mathrm{CgA}_{250-301}\right)$ és WE-14 ( $\left.\mathrm{CgA}_{324-337}\right)$ elnevezésű hasítási polipeptidszármazékai is, amelyek cukoranyagcserében, illetve a diabetes mellitus patomechanizmusában játszott szerepéről több, az elmúlt pár évben megjelent tanulmány számolt be.

\section{A pankreasztatin szerepe a szénhidrát- anyagcserében, a gestatiós és a 2-es típusú cukorbetegségben}

A PST képes növelni a vércukorszintet mind a glukózstimulált, mind a stimulálatlan inzulinszekréció gátlása révén. Gátolja továbbá a primer hepatocyták inzulinstimulált glikogenezisét, és csökkenti a zsírsejtek inzulinstimulált lipidszintézisét, illetve a leptin expresszióját és szekrécióját. ${ }^{12,13,23,24}$ Több szerző kutatási eredményei alapján a PST inzulingátlása az NO-útvonalak aktiválásán keresztül történik: a NO-ról ismert, hogy képes gátolni az inzulinszekréciót, ${ }^{25}$ a pankreasztatin pedig képes fokozott NOtermelést indukálni. ${ }^{26}$

Gayen és mtsai olyan CgA-KO egereket hoztak létre, amelyeknél magas vérnyomást, a plazmában jelentősen magasabb katekolamin-, adipokin-, alacsonyabb interleukin-6- és NO-koncentrációkat igazoltak a nem génkiütött egyedekhez képest. A KO egereknél megfigyelhető euglykaemiás állapotot a máj fokozott inzulinszenzitivitása tartotta fenn, amelyet a foszfoenol-piruvát karboxikináz és a glukóz-6-foszfatáz mRNS-ek szupresszálásával gátoltak, ekkor az egerek vércukorszintje szignifikánsan csökkent. PST külső forrásból történő adminisztrációja esetén - a foszfoenol-piruvát karboxikináz és a glukóz-6-foszfatáz mRNS-ének hiányában is - ismét euglykaemiás állapotot figyeltek meg. A PST kiváltotta újbóli transzkripció proteinkináz C- és NO-szintetáz-függő folyamat, amely végső soron az inzulin szignalizációját gátolja. Mindezek miatt a szerzők úgy gondolják, hogy a PST az inzulinszenzitivitás és a glukózhomeosztázis negatív regulátoraként játszik fontos szerepet. A KO egerekben glukóz beadását követően 7, 15 és 30 perccel a glukóz stimulálta inzulinszekréció a kiindulási értékhez képest többszörösére emelkedik a vad típusú egerekéhez viszonyítva. $\mathrm{Az}$ egerek magas zsírtartalmú diétával történő táplálása elhízáshoz, hyperinsulinaemiához és fokozott gyulladáshoz vezet. ${ }^{27}$ A magas zsírtartalmú diétán tartott $\mathrm{CgA}-\mathrm{KO}$ egerek inzulinérzékenysége kevésbé károsodott, mint a vad típusú egereké. ${ }^{28}$

Humán vizsgálatok során a PST jelentős szerepét igazolták a vércukor és az inzulin fiziológiás homeosztázisában. Kontrollszemélyekkel összehasonlítva a T2DM-es betegek étkezés előtti PST-szintjei nem különböznek. 75 g-os OGTT során a 180. percben mért PST-koncentrációk T2DM esetében szignifikánsan magasabbak a 0 perces értékekhez képest, míg a kontrollszemélyeknél nem figyelhető meg szignifikáns változás. ${ }^{29}$ Sánchez-Margalet munkacsoportja nem-obes, esszenciális hypertoniás betegeknél vizsgálta a PST-szinteket egészséges kontrollokhoz hasonlítva. A hypertoniás betegeket 3 alcsoportba sorolták: normoinsulinaemiás, hyperinsulinaemiás és glukózintoleranciás. A 75 g-os OGTT 0. percében mért PST-szintek a normoinsulinaemiás csoportban, míg az OGTT-t követően mindhárom betegcsoportban szignifikánsan magasabbak. ${ }^{30}$ Kontrollegyénekhez hasonlítva, gestatiós diabetesben 
emelkedett pankreasztatinszinteket figyeltek meg. ${ }^{31}$ Pozitív korrelációt figyeltek meg az egyes catecholaminok (epinefrin és norepinefrin) koncentrációjának emelkedése és a kromograin-A szintje között is.

Kontroll obes betegekben a plazma PST-szintje nem különbözött statisztikailag a kontrollszemélyekben mérttől, azonban az obes és T2DM-es betegek koncentrációi szignifikánsan magasabbak. A betegek PST-koncentrációi a kiindulási állapothoz képest jelentős (kb. 7 kg-os) súlyvesztéssel járó, kontrollált, 2 hónapos fogyókúrát követően sem változtak meg. ${ }^{32}$

T2DM-betegekben a postprandialis PST-szint kismértékű, de kontrollszemélyekkel összehasonlítva szignifikáns emelkedését figyelték meg. ${ }^{29}$ A betegeknél észlelt koncentrációemelkedés hátterében a PST-t termelő hasnyálmirigysejtek glukózérzékenysége állhat: T2DM-ben a PST hiperszekréciója szerepet játszhat a glukóz indukálta inzulinszekréció gátlásában, amely végső soron magas vércukorértékeket, hyperglykaemiát válthat ki.

\section{Kromogranin-A 2-es típusú cukorbetegségben}

Soell és kutatócsoportja 2010-ben dolgozta ki azt az SDS-PAGE és immunoblottolásos módszert (Western blot) felhasználó eljárást, amelynek segítségével T2DM-es és egészséges kontrollszemélyek

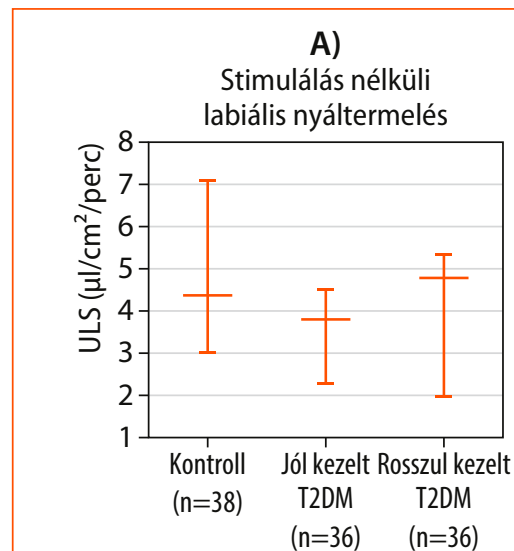

D)

Kromogranin-A-

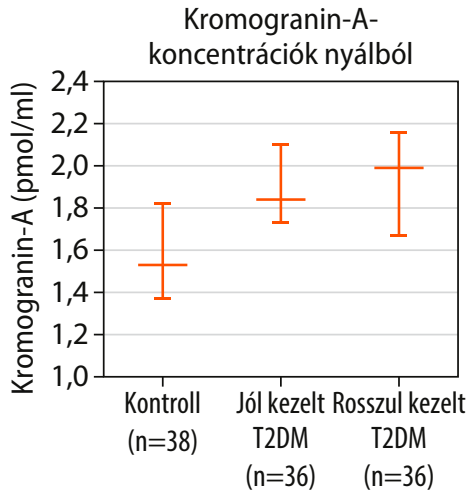

B)

Stimulálás nélküli teljes nyáltermelés

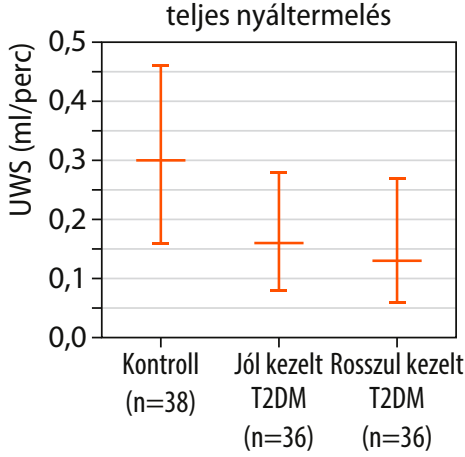

C)

Stimulált

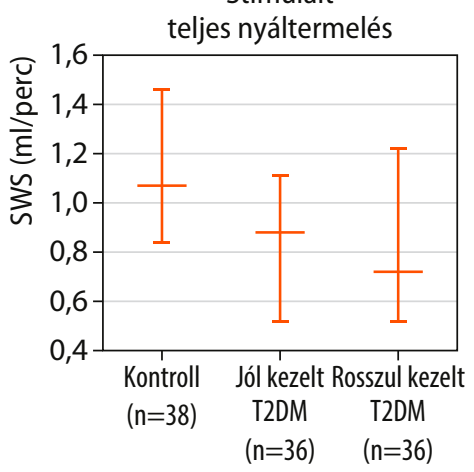

E)

Kromogranin-Akoncentrációk plazmából

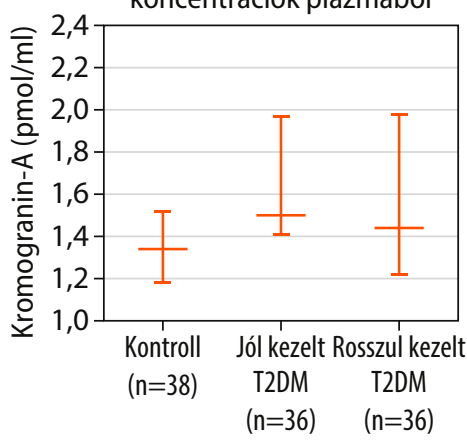

2. ábra. Kontroll $(n=38)$, jól ( $n=36)$ és rosszul $(n=36)$ kezelt T2DM-es személyek $A)$ stimulálás nélküli labiális (ULS), B) stimulálás nélküli teljes (UWS) és C) stimulált teljes nyáltermelése (SWS), illetve kromogranin-A D) nyál-és E) plazmakoncentrációi (alsó kvartilis - medián - felső kvartilis). Mindegyik nyáltermelési paraméter esetében szignifikánsan alacsonyabb értékek figyeletőek meg a betegcsoportokban (ULS: $p=0,027$, UWS: $p=0,002$, SWS: $p=0,026$ ), amelyekhez szignifikánsan magasabb nyál- és plazma-CgA-értékek tartoztak (nyál-CgA: $p<0,001$, plazma-CgA: $p=0,019$ ) 
CgA-génexpressziós szintjeit határozták meg nyálból. Eredményeik alapján a vizsgált T2DM-es populációban a $\mathrm{CgA}$ termelése több mint négyszerese volt az egészséges egyének termelésének. ${ }^{33}$

Soell megfigyeléseit követően egy brazil munkacsoport is vizsgálni kezdte a nyálban található $\mathrm{CgA}$ különböző hatásait T2DM-es személyekben. Első vizsgálatukba jól és rosszul kezelt T2DM-es betegeket, illetve kontrollszemélyeket vontak be. Mind a nyálban, mind a vérben mérhető CgA-szintek szignifikánsan magasabbak voltak T2DM-betegek esetében, illetve a magasabb CgA-koncentrációk gyakrabban voltak megfigyelhetőek a rosszul kezelt betegek esetében. Továbbá mindkét T2DMcsoportban szignifikánsan nagyobb gyakorisággal fordultak elő a különböző fogászati szövődmények (fogágyvérzések, klinikai tapadásveszteség, magasabb plakkindex). ${ }^{34}$

Szintén a brazil Kogawa és munkacsoportjának megfigyelése, hogy a stimulálás nélküli labiális, stimulálás nélküli teljes és a stimulált teljes nyáltermelés T2DM-ben szignifikánsan alacsonyabb, amelyhez kapcsolódóan magasabb $\mathrm{CgA}$-szinteket mértek mind nyálból, mind plazmából (2. ábra). A fenti eredmények mellett a vizsgálat során két CgA-génpolimorfizmust (T-415C és Glu264Asp) is igazoltak, amelyek megléte T2DM-ben a nyálmirigyek alulmüködését, illetve a nyálban mérhető magasabb CgA-koncentrációt okozhatják. ${ }^{35}$

\section{Kromogranin-A és hasítási termékei az 1-es típusú cukorbetegségben}

A T1DM kialakulásában a $\beta$-sejtek ellen termelődő autoreaktív T-sejteknek jut központi szerep. A pancreas $\beta$-sejtjeit elpusztító lymphocyták meglétét mind humán, mind pedig a T1DM modellállataiban, a NOD egerekben igazolták. A betegség kialakulása előtt a diabetogén hatású, autoreaktív T-sejt-csoportok kimutatása a $\beta$-sejtek pusztulását prognosztizálja, illetve biomarkerei lehetnek a prediabeteses állapotoknak. ${ }^{11}$

Kromogranin-A hasitási termékeinek szerepe az 1-es típusú cukorbetegségben

Haskins és munkacsoportja már 1989-ben igazolni tudta NOD egerekben a diabetogén autoantitestek jelenlétét a hasnyálmirigy szigetsejtjeiben, ${ }^{36}$ azonban az autoimmunitást kiváltó molekulák közül sokat csak később fedeztek fel. Az egyik újonnan felfedezett autoantigén a $\mathrm{CgA}$ egyik hasítási terméke, a WE-14, amelynek CD4 ${ }^{+}$T-sejkre gyakorolt autoimmunitást kiváltó hatását Stadinski és mtsai fedezték fel 2010-ben. ${ }^{11}$ A fehérje szerkezetének elemzésekor megállapították, hogy a WE-14-en megtalálható antigénmotívum ellenére hiányoznak róla azok az $\mathrm{N}$-terminális aminosavak, amelyek elfoglalnák az MHC II antigénjének az I-A ${ }^{\mathrm{g} 7}$ p1-p4 közötti peptidkötő helyeit, amelyek rendszerint szükségesek a stabil MHC II kötéshez. Ezek alapján a WE-14 C-terminálisa feltételezhetően aspecifikus kölcsönhatást alakít ki az I-A ${ }^{\mathrm{g} 7}$ egy olyan kötőhelyén, amely kívül esik a szokásos peptidkötő barázdán. ${ }^{11}$

NOD egerek különböző gastro-entero-pancreaticus szövetmintáiban vizsgálta immunológiai módszerekkel Gleeson és munkacsoportja, hogy a hasnyálmirigyen kívül máshol is megfigyelhető-e autoimmunitás a fehérjével szemben. E kísérletek során a hasnyálmirigy $\beta$-sejtjein kívül az egyéb szövetekben a WE-14 indukálta autoimmun folyamatok nem voltak igazolhatóak. ${ }^{37}$ Hogy a $\beta$-sejteken kívül más szövetekben miért nem figyelhető meg autoimmun reakció, az jelenlegi ismereteink szerint még nem világos, bár több hipotézis is napvilágot látott: Stadinskiék szerint például a WE-14 csak hasnyálmirigy-specifikus poszttranszlációs módosításokat követően működhet autoantigénként. ${ }^{11}$ Egy másik elmélet szerint az autoimmunitás kialakulhat a csecsemőmirigy fejlődése során is: az embrionális thymus medulláris epitheliumsejteken végzett kísérletek során a CgA-gén mRNS-e nem expresszálódott detektálható mennyiségben, és feltételezhetően a CgA-mRNS ezen hiánya következményes oka, hogy nem szelektálódnak ki kellő mennyiségben a CgA-ra, illetve WE-14-re érzékeny T-sejtek a thymusból. ${ }^{38}$

A szöveti TGáz természetes körülmények között a különböző fehérjék dezamidálását (glutamin lebontása glutaminsavvá), illetve keresztkötéseiknek az átalakítását (a glutamin és lizin aminosav-oldalláncai közötti izopeptidkötés kialakítása) katalizálja. ${ }^{39} \mathrm{~A}$ WE-14 fehérje antigénaktivitása a molekula eredeti formájában a legtöbb T-sejt-klónnal gyenge kötést alakít ki, azonban TGáz-kezelés hatására a molekula reaktivitása drámaian megnő: a BDC2.5 T-sejt-klónok esetében 44,3-szor, a BDC-10.1 
klónoknál 8,6-szor, míg a BDC-9.46 klónoknál 2,1-szer erősebb, mint a módosítatlan fehérje esetében. ${ }^{40} \mathrm{~A}$ WE-14 magasabb antigenitását a keresztkötések átalakítása okozza. A dezamidációs módosítások esetén az antigenitás erőssége a módosítatlan molekuláéhoz hasonló.

A NOD egerekkel végzett kísérletek ismeretében Gottlieb és mtsai frissen diagnosztizált T1DMes és egészséges kontrollszemélyek vérmintáiból vizsgálta, hogy szintén kimutatható-e a WE-14 antigenitása. Eredményeik megegyeztek a NOD egerek esetében kapott eredményekkel: a WE-14 az autoreaktív T-sejtek célpontjaként szolgál az újonnan diagnosztizált T1DM-es betegeknél, míg az egészséges kontrollszemélyeknél antigenitás nem igazolható. A megfigyelt autoimmun hatás erőssége a TGáz enzim mintákhoz való hozzáadásával tovább volt fokozható. ${ }^{41}$

A transzglutamináz általi módosítás mellett Jin és munkacsoportja további fehérjemódosításokat is feltételezett: a fehérje poszttranszlációs módosításai kiegészülhetnek különböző aminosavlánc-addíciókkal is, amelyek a fehérje $\mathrm{N}$-terminális végéhez kapcsolódnak. ${ }^{42}$ Az RLGL aminosavszakasszal módosított WE-14 fehérjemolekulát reagáltatták különböző NOD egér T-sejt-hybridoma vonalakkal. Az így kialakított RLGL-WE-14 már alacsony koncentrációban is képes kapcsolatba lépni a Tsejt-receptorok $\mathrm{V} \alpha, \mathrm{J} \alpha, \mathrm{V} \beta, \mathrm{J} \beta$ és CDR3 hurkainak különböző szegmenseivel, így kialakítva az immunreakciót a pancreas szigetsejtjeiben. Az N-terminális végén extraaminosavakkal kapcsolt WE-14 kialakulásában nagy szerepet gondolnak a reverz proteolízisnek, avagy transzpeptidációs mechanizmusoknak, amelyek a prohormon-konvertáz által vezérelt, teljes CgA fehérjéről történő lehasadását követően játszódnak le.

A T1DM kialakulása során szerepet játszó autoimmun folyamatot sokáig kizárólagosan $\mathrm{CD}^{+}{ }^{+}$T-sejt mediálta folyamatnak feltételezték, később azonban igazolódott a $\mathrm{CD} 8^{+} \mathrm{T}$-sejtek szerepe is. ${ }^{43}$ Li és mtsai feltételezték, hogy a CD4pozitivitást mutató WE-14 mellett keletkezhetnek a szervezetben olyan CgA-hasítási termékek is, amelyek a T-lymphocyták egy másik ismert diabetogén szubpopulációját, a $\mathrm{CD} 8^{+} \mathrm{T}$-sejteket aktiválják a CgA-val szemben. ${ }^{44}$ Vizsgálatuk során HLA-A*0201 transzgenikus egerek és maximum 1 éven belül diagnosztizált HLA-A*0201-pozitív, illetve -negatív T1DM-es betegek mintáit elemezték. Az egérből származó $\mathrm{mCgA}_{10-19}$ és $\mathrm{mCgA}_{43-52}$ és a humán $\mathrm{CgA}_{10-19}$ és $\mathrm{CgA}_{43-52} \mathrm{CgA}$-fehérjeszármazékokkal reagáltatott $\mathrm{CD} 8^{+} \mathrm{T}$-sejteknél jelentôs interferon- $\gamma$ - és perforintermelést igazoltak. A CgA-reaktív T-sejt-klónok mellett egy másik CD8 ${ }^{+}$T-sejt-klónpopuláció intenzív interleukin-17termelésbe kezdett - ezek interleukin-17-termelését az immundomináns HLA-A*0201-korlátozott egér inzulin A-lánc ( $\left.\mathrm{mIns}_{2-10}\right)$ epitop indukálta $\mathrm{CD} 8^{+} \mathrm{T}$-sejteknél is igazolták ${ }^{45}$ - amely szintén szerepet játszhat a betegség kialakításában.

Kromogranin-A szerepe az 1-es típusú cukorbetegségben

Baker munkacsoportjának 2016-ban közölt eredményei alapján ${ }^{46}$ a CgA-deficiens KO egereknél $\left(\mathrm{NOD} \mathrm{ChgA} \mathrm{A}^{-/-}\right.$) a vad típusú NOD egerekhez képest T1DM nem, vagy csak nagyon kis számban alakul ki. A 12 hónapon át tartó megfigyeléseik során a betegség a vizsgálatba vont vad típusú nőstény NOD egerek több mint 90\%-ánál volt megfigyelhető, míg a NOD.ChgA ${ }^{-1-}$ nőstények esetében a 118 egyedből csupán 3 mutatta a betegség tüneteit. A megfigyelés ideje alatt a hím NOD.ChgA ${ }^{-/-}$egereknél pedig a betegség nem is alakult ki. Az 52 hetes megfigyelést követően patológiai módszerekkel vizsgálták meg az egerek hasnyálmirigyét. A NOD. $\mathrm{ChgA}^{-/-}$egereknél a hasnyálmirigy Langerhans-szigeteiben kialakuló gyulladás, az insulitis csupán az állatok kevesebb mint 20\%-ában volt igazolható. Ugyanez a vad típusú egyedeknél 100\%-ban jelen volt. A kioperált hasnyálmirigyekből immunológiai vizsgálatokat is végeztek. Kimutatták, hogy a NOD. $\mathrm{ChgA}^{-/-}$egerek hasnyálmirigyében, a vad típusú NOD egerekéhez hasonlítva, az infiltrációra képes $\mathrm{CD}^{+}, \mathrm{CD}^{+}, \mathrm{CD} 19^{+}$és CD45 ${ }^{+}$T-sejt-klónok száma szignifikánsan alacsonyabb. ${ }^{46}$

A T1DM gyakran társulhat autoimmun gastritisszel, ${ }^{47}$ aminek a betegek kb. 4-9\%-ában következménye lehet, hogy az enterokromaffinszerü sejtek hyperplasiás proliferációjából karcinoid tumorok fejlődnek ki ${ }^{48}$ Munkacsoportunk egy korábban közölt esettanulmányában egy 29 éves, 6 éve 1-es típusú diabeteses, gastritis talaján kialakult, emelkedett $\mathrm{CgA}$-val járó neuroendokrin tumorban szenvedő nőbeteg esetét mutatta be. A tumor felismerésekor a beteg szérum-CgA-koncentrációja 
a normál tartomány felső határának (>98,1ng/ml) $\mathrm{kb}$. háromszorosa volt, ami a primer neuroendokrin daganat sebészi eltávolítását követően rendeződött. ${ }^{47} \mathrm{~A}$ publikáció megjelenését követően további 3, T1DM-es betegnél lezajlott, hasonló esettel találkoztunk. Mindegyik esetben a tumor sebészi eltávolítását követően a szérum CgA-szintje normalizálódott.

\section{Szérum-kromogranin-A vizsgálata 98 1-es típusú cukorbeteg személynél}

Saját, CgA-val kapcsolatos kutatásunkba 98 T1DMes beteget vontunk be. Vizsgálatunk során arra kerestük a választ, hogy milyen $\mathrm{CgA}$-szintek figyelhetők meg a Semmelweis Egyetem, II. sz. Belgyógyászati Klinika Anyagcsere ambulanciáján kezelt T1DMes betegekben. A betegek CgA-szintjei mellett

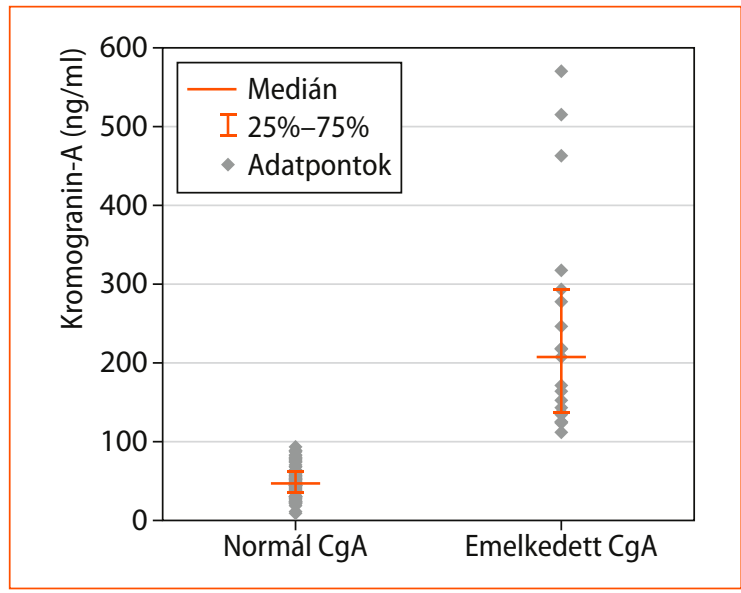

3. ábra. A szérum kromogranin-A-koncentrációja a Normál CgA $(49,3 \pm 20,02 \mathrm{ng} / \mathrm{ml})$ és az Emelkedett CgA $(289,2 \pm 278,38 \mathrm{ng} / \mathrm{ml})$ csoportban $\left(p=2,64 \times 10^{-12}\right)$ kíváncsiak voltunk továbbá arra is, hogy adott $\mathrm{CgA}$ szintek mellett a betegeknél milyen gyakorisággal figyelhető meg hypertonia, illetve a T1DM-hez gyakran társuló autoimmun betegségek.

A résztvevőknél alkalmazott gyomorsavcsökkentő kezelést a vérvétel napja előtt egy héttel ideiglenesen leállítottuk. ${ }^{16,19,20}$ A vizsgálatban részt vevő személyeknél írásbeli hozzájárulásuk és anamnézisük felvételét követően éhgyomri vérvétel történt. A levett vérmintákból a CgA-szint meghatározása a Cisbio Bioassays CGA-RIACT RIA kitjével történtek. Statisztikai elemzéseinket az R for Windows version 3.4.2 és az RStudio version 1.1.383 programmal végeztük. Az adatok értékeléséhez felhasználtunk Wilcoxon-Mann-Whitneyféle U-tesztet, és Yates-korrekcióval alkalmazott $\chi^{2}$-teszteket. A vizsgálatot a Semmelweis Egyetem Tudományos Etikai Bizottsága engedélyezte.

A betegeket szérum-CgA-szintjeik alapján két csoportba soroltuk. A normál tartományon belüli szérum-CgA-szinttel $(19,4-98,1 \mathrm{ng} / \mathrm{ml})$ rendelkező betegek csoportjába 77 fő került besorolásra (Normál CgA csoport). Míg a normál tartományhoz képest emelkedett CgA-szinttel (>98,1 ng/ml) rendelkező betegek csoportjába 21 beteg került (Emelkedett CgA csoport) (3. ábra).

A Normál CgA csoporthoz képest (63-ból 24 fö) az Emelkedett CgA csoportban (16 betegből 8 fó) szignifikánsan gyakrabban figyeltük meg az 1-es típusú cukorbetegséghez társult hypertoniát $(\mathrm{p}=0,00378)$ és anaemia perniciosát $(\mathrm{p}=0,005515)$ (1. táblázat).

Saját eredményeink az irodalomból ismert adatokhoz hasonlóak: az emelkedett CgA-szintek mellett a hypertonia magasabb gyakorisága igazolható. Mindezek alapján a CgA mint a diabeteshez társuló hypertonia kialakulásának egy esetleges új patogenetikai tényezőjeként is szóba jöhet.

1. táblázat. Az 1-es típusú cukorbetegséggel társuló hypertonia és egyes, a T1DM gyakori autoimmun eredetű társbetegségeinek százalékos előfordulása a Normál CgA és az Emelkedett CgA csoportokban

\begin{tabular}{|c|c|c|c|}
\hline Társbetegség & Normál CgA $(\mathbf{n = 7 7})$ & Emelkedett CgA (n=21) & p-érték $\left(\mathbf{X}^{2}\right.$-teszt) \\
\hline Hypertonia & $31,2 \%$ & $52,4 \%$ & $\mathrm{p}=0,003780$ \\
\hline Anaemia perniciosa & $5,2 \%$ & $19,0 \%$ & $\mathrm{p}=0,005515$ \\
\hline Coeliakia & $3,9 \%$ & $0,0 \%$ & $\mathrm{p}=0,1297$ \\
\hline Alopecia & $5,2 \%$ & $0,0 \%$ & $\mathrm{p}=0,07004$ \\
\hline Vitiligo & $5,2 \%$ & $4,8 \%$ & $\mathrm{p}=1,0$ \\
\hline
\end{tabular}




\section{Összegzés}

A CgA az emberi szervezetben különböző szervek endokrin és neuroendokrin sejtjeiben termelődik. Proteolitikus módosításokat követően alakul át szekretálódó, extracellulárisan működő, biológiailag aktív peptiddé, amely a szervezetben további, kisebb molekulatömegü termékekké hasadhat tovább. A CgA-ból kialakuló fehérjék, mint a pankreasztatin, a WE-14 és további formák jelentős és specifikus biológiai hatással rendelkeznek.

A szérum-CgA meghatározását gyakran használják a tumordiagnosztikában. Az emelkedett értékek jellemzően különböző adrenális, illetve gastrointestinalis neuroendokrin sejtes eredetű tumoros elváltozásokra utal(hat)nak. A szérumCgA-szintek mérése a tumorok progressziójáról, kiújulásáról vagy a kezelésre adott válaszról is fontos információkat szolgáltathat.

A legújabb tanulmányok szerint a fentiek mellett a Cg-A hasítási termékei közül a WE-14 és a pankreasztatin szerepet játszik a szénhidrátanyagcserében és kapcsolatot mutat a cukorbetegség különböző formáival. Míg a T1DM esetében a CgA és származékának, a WE-14-nek hatása bizonyítottan a betegség kialakulásában, patomechanizmusában játszik szerepet, addig a T2DM esetében a pontos mechanizmusok háttere nem ismert, a magasabb szérum- és nyálkoncentrációk mellett csak közvetett megfigyelések ismertek az irodalomból.

Saját, T1DM-es személyekkel végzett vizsgálatunkban kapott eredmények alapján az Emelkedett $\mathrm{CgA}$ csoportban szignifikánsan nagyobb gyakorisággal fordul elő néhány, a T1DM mellett megjelenő társ- és kísérő autoimmunbetegség, mint pl. a hypertonia és az anaemia perniciosa.

Mindezen eredmények fényében a $\mathrm{CgA}$ és a diabetes mellitus kapcsolatának további elemzését - mind T1DM-ben, mind T2DM-ben a háttérmechanizmusok felderítését és az elméleti irányultságú tanulmányok mellett hiánypótló klinikai vizsgálatokat - tartjuk szükségesnek.

\section{Köszönetnyilvánítás}

A közlemény megírását, illetve a kapcsolódó kutatómunkát az OTKA K-116128 és a Magyar Diabetes Társaság kutatási pályázata támogatta.
Irodalom

1. Blaschko $H$, Comline RS, Schneider $F H$, Silver $M$, Smith $A D$ : Secretion of a chromaffin granule protein, chromogranin, from the adrenal gland after splanchnic stimulation. Nature 1967; 215(5096): 58-59. doi:10.1038/215058a0

2. Winkler H, Fischer-Colbrie R: The chromogranins $A$ and $B$ : the first 25 years and future perspectives. Neuroscience 1992; 49(3): 497-528. doi:10.1016/0306-4522(92)90222-N

3. Hendy GN, Bevan S, Mattei MG, Mouland AJ: Chromogranin A. Clin Invest Med 1995; 18(1): $47-65$.

4. Angeletti RH, Hickey WF: A neuroendocrine marker in tissues of the immune system. Science 1985; 230(4721): 89-90. doi:10.1126/science.3898368

5. Nolan JA, Trojanowski JQ, Hogue-Angeletti R: Neurons and neuroendocrine cells contain chromogranin: detection of the molecule in normal bovine tissues by immunochemical and immunohistochemical methods. J Histochem Cytochem 1985; 33(8): 791-798. do: 10.1177/33.8.3894497

6. Takiyyuddin MA, Neumann HP, Cervenka JH, Kennedy B, Dinh TQ, Ziegler MG, et al.: Ultradian variations of chromogranin A in humans. Am J Physiol 1991; 261(4 Pt 2): R939-944. doi:10.1152/ajpregu.1991.261.4.R939

7. Herold Z, Nagy P, Patocs A, Somogyi A: A kromogranin-A és a belöle lehasadó WE-14 szerepe az 1-es típusú cukorbetegség kialakulásában. Orvosi Hetilap 2015; 156(5): 163-170. doi:10.1556/0H.2015.30087

8. Louthan 0: Chromogranin a in physiology and oncology. Folia Biol (Praha) 2011; $57(5): 173-181$.

9. Curry WJ, Shaw C, Johnston CF, Thim L, Buchanan KD: Isolation and primary structure of a novel chromogranin A-derived peptide, WE- 14 , from a human midgut carcinoid tumour. FEBS Lett 1992; 301(3): 319-321. doi:10.1016/0014-5793(92)80266-J

10. Guillemot J, Guerin M, Thouennon E, Montero-Hadjadje M, Leprince J, Lefebvre $\mathrm{H}$, et al: Characterization and plasma measurement of the WE-14 peptide in patients with pheochromocytoma. PLoS One 2014; 9(2): e88698. doi:10.1371/journal.pone. 0088698

11. Stadinski BD, Delong T, Reisdorph N, Reisdorph R, Powell RL, Armstrong M, et al.: Chromogranin $A$ is an autoantigen in type 1 diabetes. Nat Immunol 2010; 11(3): 225-231. doi: $10.1038 /$ ni. 1844

12. Tatemoto K, Efendic S, Mutt V, Makk G, Feistner GJ, Barchas JD: Pancreastatin, a novel pancreatic peptide that inhibits insulin secretion. Nature 1986; 324(6096): 476-478. doi:10.1038/324476a0

13. Schmidt WE, Creutzfeldt W: Pancreastatin - a novel regulatory peptide? Acta Oncol 1991; 30(4): 441-449. doi:10.3109/02841869109092399

14. Eriksson B, Oberg $K$, Stridsberg $M$ : Tumour markers in neuroendocrine tumours. Digestion 2000; 62(Suppl 1): 33-38. doi:10.1159/000051853

15. Deftos $\mathrm{L}$ : Chromogranin A: its role in endocrine function and as an endocrine and neuroendocrine tumor marker. Endocr Rev 1991; 12(2): 181-187. doi:10.1210/edrv-12-2-181

16. Vinik Al, Silva MP, Woltering EA, Go VL, Warner R, Caplin M: Biochemical testing for neuroendocrine tumors. Pancreas 2009; 38(8): 876-889. doi:10.1097/MPA.0b013e3181bc0e77

17. Hsiao RJ, Mezger MS, O'Connor DT: Chromogranin A in uremia: progressive retention of immunoreactive fragments. Kidney Int 1990; 37(3): 955-964. doi:10.1038/ki.1990.71

18. Sciola V, Massironi S, Conte D, Caprioli F, Ferrero S, Ciafardini C, et al: Plasma chromogranin a in patients with inflammatory bowel disease. Inflamm Bowel Dis 2009; 15(6): 867-871. doi:10.1002/ibd.20851

19. Pregun I, Herszenyi L, Juhasz M, Miheller P, Hritz I, Patocs A, et al.: Effect of proton-pump inhibitor therapy on serum chromogranin a level. Digestion 2011; 84(1): 22-28. doi:10.1159/000321535 
20. Glinicki P, Jeske W: Chromogranin A $(\mathrm{GA})$ - the influence of various factors in vivo and in vitro, and existing disorders on it's concentration in blood. Endokrynol Pol 2010; 61(4): 384-387.

21. Ogurtsova K, da Rocha Fernandes JD, Huang Y, Linnenkamp U, Guariguata $\mathrm{L}$, Cho NH, et al: IDF Diabetes Atlas: Global estimates for the prevalence of diabetes for 2015 and 2040. Diabetes Res Clin Pract 2017; 128: 40-50. doi:10.1016/j.diabres.2017.03.024

22. Broedbaek K, Hilsted L: Chromogranin A as biomarker in diabetes. Biomark Med 2016; 10(11): 1181-1189. doi:10.2217/bmm-2016-0091

23. Gonzalez-Yanes C, Sanchez-Margalet V: Pancreastatin, a chromogranin A-derived peptide, inhibits leptin and enhances UCP-2 expression in isolated rat adipocytes. Cell Mol Life Sci 2003; 60(12): 2749-2756. doi:10.1007/s00018-003-3346-7

24. Sanchez V, Lucas M, Calvo JR, Goberna R: Glycogenolytic effect of pancreastatin in isolated rat hepatocytes is mediated by a cyclic-AMPindependent $\mathrm{Ca}(2+)$-dependent mechanism. Biochem J 1992; 284 (Pt 3): 659-662. doi:10.1042/bj2840659

25. Mosen H, Salehi A, Henningsson R, Lundquist I: Nitric oxide inhibits, and carbon monoxide activates, islet acid alpha-glucoside hydrolase activities in parallel with glucose-stimulated insulin secretion. J Endocrinol 2006; 190(3): 681-693. doi:10.1677/joe.1.06890

26. Sanchez-Margalet V, Gonzalez-Yanes C, Najib S: Pancreastatin, a chromogranin A-derived peptide, inhibits DNA and protein synthesis by producing nitric oxide in HTC rat hepatoma cells. J Hepatol 2001; 35(1): 80-85. doi:10.1016/S0168-8278(01)00071-X

27. Gayen JR, Saberi M, Schenk S, Biswas N, Vaingankar SM, Cheung WW, et al.: A novel pathway of insulin sensitivity in chromogranin A null mice: a crucial role for pancreastatin in glucose homeostasis. J Biol Chem 2009; 284(42): 28 498-28509. doi:10.1074/jbc.M109.020636

28. Bandyopadhyay GK, Lu M, Avolio E, Siddiqui JA, Gayen JR, Wollam J, et al.: Pancreastatin-dependent inflammatory signaling mediates obesity-induced insulin resistance. Diabetes 2015; 64(1): 104-116. doi:10.2337/db13-1747

29. Funakoshi A, Tateishi K, Shinozaki H, Matsumoto M, Wakasugi H: Elevated plasma levels of pancreastatin (PST) in patients with non-insulindependent diabetes mellitus (NIDDM). Regul Pept 1990; 30(2): 159-164. doi:10.1016/0167-0115(90)90056-3

30. Sanchez-Margalet V, Valle M, Lobon JA, Maldonado A, Escobar-Jimenez F, Olivan J, et al.: Increased plasma pancreastatin-like immunoreactivity levels in non-obese patients with essential hypertension. J Hypertens 1995; 13(2): 251-258. doi:10.1097/00004872-199502000-00013

31. Sanchez-Margalet V, Lobon JA, Gonzalez A, Fernandez-Soto ML, EscobarJimenez F, Goberna R: Increased plasma pancreastatin-like levels in gestational diabetes: correlation with catecholamine levels. Diabetes Care 1998; 21(11): 1951-1954. doi:10.2337/diacare.21.11.1951

32. O'Connor DT, Cadman PE, Smiley C, Salem RM, Rao F, Smith J, et al: Pancreastatin: multiple actions on human intermediary metabolism in vivo, variation in disease, and naturally occurring functional genetic polymorphism. $J$ Clin Endocrinol Metab 2005; 90(9): 5414-5425. doi:10.1210/jc.2005-0408

33. Soell M, Feki A, Hannig M, Sano H, Pinget M, Selimovic D: Chromogranin A detection in saliva of type 2 diabetes patients. Bosn J Basic Med Sci 2010 10(1): 2-8. doi:10.17305/bjbms.2010.2725

34. Kogawa EM, Grisi DC, Falcao DP, Amorim IA, Rezende TM, da Silva IC, et al.: Impact of glycemic control on oral health status in type 2 diabetes individuals and its association with salivary and plasma levels of chromogranin A. Arch Oral Biol 2016; 62: 10-19. doi:10.1016/j.archoralbio.2015.11.005

35. Kogawa EM, Grisi DC, Falcão DP, Amorim IA, Rezende TM, da Silva IC, et al. Salivary function impairment in type 2 Diabetes patients associated with concentration and genetic polymorphisms of chromogranin A. Clin Oral Investig 2016; 20(8): 2083-2095. doi:10.1007/s00784-015-1705-2
36. Haskins K, Portas M, Bergman B, Lafferty K, Bradley B: Pancreatic isletspecific T-cell clones from nonobese diabetic mice. Proc Natl Acad Sci U S A 1989; 86(20): 8000-8004.

37. Gleeson CM, Curry WJ, Johnston CF, Buchanan KD: Occurrence of WE-14 and chromogranin A-derived peptides in tissues of the human and bovine gastro-entero-pancreatic system and in human neuroendocrine neoplasia. J Endocrinol 1996; 151(3): 409-420. doi:10.1677/joe.0.1510409

38. Anderson MS, Venanzi ES, Klein L, Chen Z, Berzins SP, Turley SJ, et al.: Projection of an immunological self shadow within the thymus by the aire protein. Science 2002; 298(5597): 1395-1401. doi:10.1126/science. 1075958

39. Sollid LM: Molecular basis of celiac disease. Annu Rev Immunol 2000; 18: 53-81. doi:10.1146/annurev.immunol.18.1.53

40. Delong T, Baker RL, He J, Barbour G, Bradley B, Haskins K: Diabetogenic T-cell clones recognize an altered peptide of chromogranin A. Diabetes 2012; 61(12): 3239-3246. doi:10.2337/db12-0112

41. Gottlieb PA, Delong T, Baker RL, Fitzgerald-Miller L, Wagner R, Cook G, et al.: Chromogranin $A$ is a T cell antigen in human type 1 diabetes. J Autoimmun 2014; 50: 38-41. doi:10.1016/j.jaut.2013.10.003

42. Jin N, Wang Y, Crawford F, White J, Marrack P, Dai S, et al.: N-terminal additions to the WE14 peptide of chromogranin $A$ create strong autoantigen agonists in type 1 diabetes. Proc Natl Acad Sci U S A 2015; 112(43): 13318-13323. doi:10.1073/pnas.1517862112

43. Tsai S, Shameli A, Santamaria P: $C^{+} 8^{+} T$ cells in type 1 diabetes. Adv Immunol 2008; 100: 79-124. doi:10.1016/50065-2776(08)00804-3

44. LiY, Zhou L, LiY, Zhang J, Guo B, Meng G, et al.: Identification of autoreactive $\mathrm{CDB}^{+} \mathrm{T}$ cell responses targeting chromogranin A in humanized NOD mice and type 1 diabetes patients. Clin Immunol 2015; 159(1): 63-71. doi:10.1016/j.clim.2015.04.017

45. Honkanen J, Nieminen JK, Gao R, Luopajarvi K, Salo HM, Ilonen J, et al.: IL17 immunity in human type 1 diabetes. J Immunol 2010; 185(3): 1959-1967. doi:10.4049/jimmunol. 1000788

46. Baker RL, Bradley B, Wiles TA, Lindsay RS, Barbour G, Delong T, et al.: Cutting Edge: Nonobese Diabetic Mice Deficient in Chromogranin A Are Protected from Autoimmune Diabetes. J Immunol 2016; 196(1): 39-43. doi:10.4049/jimmunol.1501190

47. Somogyi A, Ruzicska E, Varga T, Racz K, Nagy G: Tünetmentes gyomorcarcinoid kialakulása 1-es típusú diabéteszben és primer hypothyreosisban szenvedö betegben. Orvosi Hetilap 2007; 148(35): 1667-1671. doi:10.1556/0H.2007,28100

48. Lahner E, Bordi C, Cattaruzza MS, lannoni C, Milione M, Delle Fave G, et al.: Long-term follow-up in atrophic body gastritis patients: atrophy and intestinal metaplasia are persistent lesions irrespective of Helicobacter pylori infection. Aliment Pharmacol Ther 2005; 22(5): 471-481. doi:10.1111/j.1365-2036.2005.02582.x

Közlésre érkezett: 2017. november 6

Közlésre elfogadva: 2018. január 18.

A levelezésért felelős szerző:

\section{Herold Zoltán}

Semmelweis Egyetem ÁOK, II. Belgyógyászati

Klinika

1088 Budapest, Szentkirályi utca 46.

E-mail: herold.zoltan@med.semmelweis-univ.hu 